\title{
KORRUPCIÓ A LABORBAN
}

\section{CORRUPTION IN THE LAB}

\author{
Scheuring István \\ az MTA doktora, tudományos tanácsadó \\ MTA-ELTE Elméleti Biológiai és Evolúciós Ökológiai Kutatócsoport, \\ MTA Ökológiai Kutatóközpont Evolúciós Rendszerek Kutatócsoport \\ istvanscheuring@gmail.com
}

\begin{abstract}
ÖSSZEFOGLALÁS
Az ember viselkedését korrupciós helyzetekben kísérletes eszközökkel is lehet vizsgálni. A cikkben az utóbbi években megjelent ilyen cikkek eredményeit foglaltam össze. Rámutattam, hogy a kísérletek alapján, mind a kooperációs helyzet, mind a kommunikáció lehetősége növeli annak esélyét, hogy immorális, korrupt döntéseket hozzanak a kísérleti személyek. Nem mellesleg az is kiderül, hogy a korrupcióra való hajlam erősen függ a kísérleti személyek értékrendjétől.
\end{abstract}

\section{ABSTRACT}

Human behaviour can be studied experimentally in corrupt situations. I have reviewed the recent papers published in this field. I have pointed out that according to the experiments both the cooperative situation and the possibility of communication enhance the chance of corrupt, immoral decisions. It turns out as well that the propensity of corruption depends on the behavioural norms of the subjects.

Kulcsszavak: kooperáció, korrupció, viselkedés gazdaságtan, morális konfliktus

Keywords: cooperation, corruption, behavioural economy, moral conflict

„Én azt hiszem, ha ez az ember holnap visszajön, akkor ez egy igen hasznavehető ember lesz: mert kérlek alássan, hosszú pályám alatt alig találtam még valakit, aki ilyen hamar és ilyen kitünően beletanult volna a dologba. Azzal a... azzal a szindikátussal nagyon jól meg lehet oldani a kérdést. Az egy... az egy zseniális gondolat... És természetesen... természetesen nála nélkül nem lehet megcsinálni...”

(Móricz Zsigmond: Rokonok)

Több mint három emberöltő telt el Móricz Zsigmond híres regényének megjelenése óta. Megszállókkal nehezített diktatúrák, demokráciák és féldemokráciák váltogatták egymást, közben világrendek formálódtak és omlottak össze, de egy 
valami nemigen változott e tájon, a kiterjedt korrupció. Habár elég pontosan érezzük, hogy mi az a korrupció, a témával tudományos igénnyel foglalkozva szükség van annak pontosabb meghatározására is. Természetesen számos, némileg eltérő definíció létezik a szakirodalomban, én a továbbiakban korrupciónak fogom tekinteni azt az erkölcstelen és/vagy törvénytelen cselekedetet, melynek hatására kölcsönösen elönyös helyzetbe kerülnek a részt vevő felek. Számunkra most nem lesz annyira fontos, de a korrupcióra az is jellemző, hogy a résztvevők közül legalább az egyik a gazdasági vagy hatalmi pozícióját használja fel a korrupt kapcsolat kialakítására (lásd például URL1). A megszerzett előny gyakran pénzben mérhető, és ahogy körülnézünk, nem ritkán nagyon sok pénzben. Jól tervezett kísérletekkel azonban a korrupció kapcsolatát az emberi természettel és a társas normákkal viszonylag csekély összegek felhasználásával is fel lehet tárni. E rövid ismertetőben éppen ilyen, a közelmúltban publikált tanulságos kísérletekről fogok beszámolni. De mielőtt ezek ismertetésébe belekezdenék, röviden összefoglalom az emberi viselkedés legfontosabb elemeit, legalábbis azokat, melyek a korrupció szempontjából kitüntetetten fontosak.

Az ember viselkedése, jellemvonásai csakúgy, mint minden állaté, az evolúció „termékei”. A különbség csupán annyi, hogy mi az evolúció során egy egészen különleges utat jártunk be. Nyilván nagyon nehéz pontosan rekonstruálni evolúciós történetünk minden fontos részletét, s nem is célom itt erre kísérletet tenni, elegendő, ha összefoglalom, hova is jutottunk el az evolúció során. Az embert a nyelv és a kognitív képességei alkalmassá teszik arra, hogy nagyon pontos képet alakítson ki a társaitól származó információk megbízhatóságáról, múltbeli és jelenlegi cselekedeteiről és szándékairól. Kognitív képességeink segítségével számon tartjuk, hogy társaink mennyire szavahihetőek, és mennyire számíthatunk rájuk egy együttmüködést igénylő helyzetben. Nagyra értékeljük az igazmondókat és az önzetlen segítőket. Éppen ezért megbízható informátornak, kooperátornak és önzetlennek lenni kifizetődő, mert az ilyen emberek hírneve és ezzel a biológiai rátermettsége is nagyobb lesz, mint a megbízhatatlan potyázóknak. Ráadásul a hosszú távú kooperációt és a megbízható kommunikációt a legtöbb emberi közösség normarendszere is támogatja, azaz helyes cselekedetnek ismeri el. Mindezen okok miatt az ember rendkívül együttmüködő lény, nem csupán a rokonainak, de a barátainak, munkatársainak és akár egy ismeretlennek is (látszólag) önzetlenül a segítségére siet, ha a helyzet úgy hozza. Összefoglalva, általános rátermettséget növelő vezérelvnek tűnik minden emberi csoportban a mondj igazat, viselkedj a csoport normáinak megfelelöen, és kooperálj szabályrendszer. Azonban e szabályok esetenként egymásnak ellentmondó viselkedésre vezetnek, ráadásul a szabályok kijátszása sokszor közvetlen elönyt is jelenthet, föleg, ha nem derül fény a csalásra. E bevezető után lássuk, hogy a laborkísérletek alapján miért és hogyan veszünk részt a javak korrupt elosztásában! 
HA MEGÉRI, HAZUDUNK, DE ÓVATOSAN!

A kísérleti összeállítás alapötlete Urs Fischbachertöl és Franziska Föllmi-Heusitől származik (Fischbacher-Föllmi-Heusi, 2013). Bár ők nem kifejezetten korrupciós helyzetet vizsgáltak, hanem inkább olyan szituációkat, ahol pusztán a hazugság a kísérleti személyeknek anyagi előnyt hozott, eredményeik a korrupció szempontjából is érdekesek. Ráadásul a később bemutatott cikkek az ő ötletük továbbfejlesztéseként jöttek létre. Megérdemlik hát, hogy részletesebben is ismertessem munkájukat.

A kísérletben részt vevő személy kap egy dobókockát a kísérlet vezetőjétől, majd egy szobában, ahol egyedül van, dob egyet a kockával. Ha hatost dob, akkor nem kap nyereményt, minden más esetben annyi svájci frank nyereményt kap, ahányas számot dobott. Ezután akárhányat dobhat, így lehetősége van meggyőződni arról, hogy a kocka nem cinkelt. A csavar a kísérletben az, hogy a dobott számot a kockát dobón kívül senki nem látja, azt a kísérleti személy beírja a számítógépbe, ezután a beírt szám alapján megkapja a nyereményt a kísérletvezetőtől. Két dolgot azonnal érzékelhetünk: ha valaki maximális nyereményre törekszik, ötöst fog mondani, függetlenül attól, hogy mit dobott, illetve ha valaki hatost, egyest vagy kettest dob, akkor nagyobb a késztetés, hogy hazudjon, mint ha hármast vagy négyest dob. A kísérletet 389 egyetemistával megismételve a bejelentett dobások az 1. ábrán látható arányban jelentek meg. Jól látszik az ábrán, hogy a valóságos egyenletes eloszlástól jelentősen eltér a kapott eloszlás. A játé-

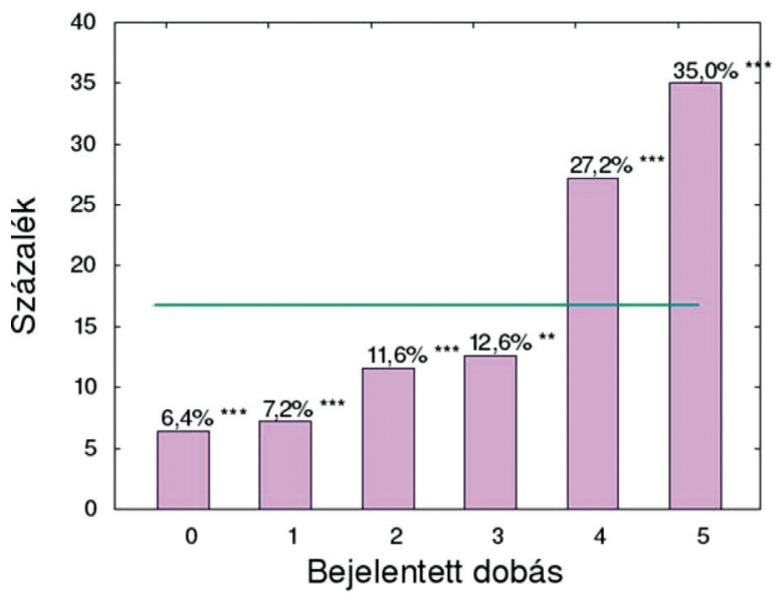

1. ábra. A kísérletben az egyes dobások aránya a bevallások alapján. A hatos dobást 0 -val jeleztük. A vízszintes vonal az egyes dobások valódi várható értékét mutatja (16,7\%). A ** 5\%-os a *** 1\%-os szignifikanciaszintű eltérést mutat a várható 16,7\%-tól.

(Fischbacher-Föllmi-Heusi, 2013 nyomán) 
kosok ritkábban mondanak hatost, egyest, kettest és hármast, mint ahányszor azt dobtak, és helyette sokkal gyakrabban mondanak négyest és ötöst. Az is látszik, hogy vannak, akik igazat mondanak, bár azzal nem nyernek sokat vagy éppen semmit sem, továbbá, ami a legváratlanabb: elég sokan nem a maximális ötös dobást hazudják, hanem a négyest! Vajon mi lehet ennek az oka?

Fischbacher és Föllmi-Heusi is feltették maguknak ezt a kérdést, ezért több kontrollkísérletet is végrehajtottak. Az igazán meglepő az, hogy abban a kontrollban, ahol nincs kockadobás, csak egy összeget kell mondani 0 és 5 frank között arra, hogy a kísérleti alany mekkora nyereséget szeretne egy kisebb kérdôíves munkáért, a megkérdezettek 15\%-a ott is négy frankot mond. Ezek alapján úgy tünik, hogy a nem maximális nyereséget hazudók többféle motivációval rendelkezhetnek: egyrészt nem túl mohónak látszani mások és maguk előtt (kocka nélküli kísérlet), másrészt elfedni a hazugságot egy kisebb nyereséggel (kockás kísérletek), esetleg csak fenntartani egy viszonylag kedvező önképet maguk elött. Egy másik kontrollkísérlet alapján kiderült az is, hogy a korábbi kísérletben részt vevők a második körben szignifikánsan nagyobb eséllyel hazudnak egy nagyobb nyeremény érdekében, mint az első körben. Továbbá, a kísérletsorozatok előtt megkérdezték a résztvevőktől, hogy mi az előzetes várakozásuk a bemondott számok eloszlásáról. A játékosoknak érdekük volt jó becslést adni, mert minél jobb becslést adott valaki, annál nagyobb jutalmat kaptak a játék végén. Az első kísérletsorozat előtt a résztvevők becslése szerint csak a hatost, egyest és a kettest dobók mondanak be ötöst, a többiek öszinték lesznek. A kísérletben való részvétel után ez a vélekedés jelentősen módosult anélkül,

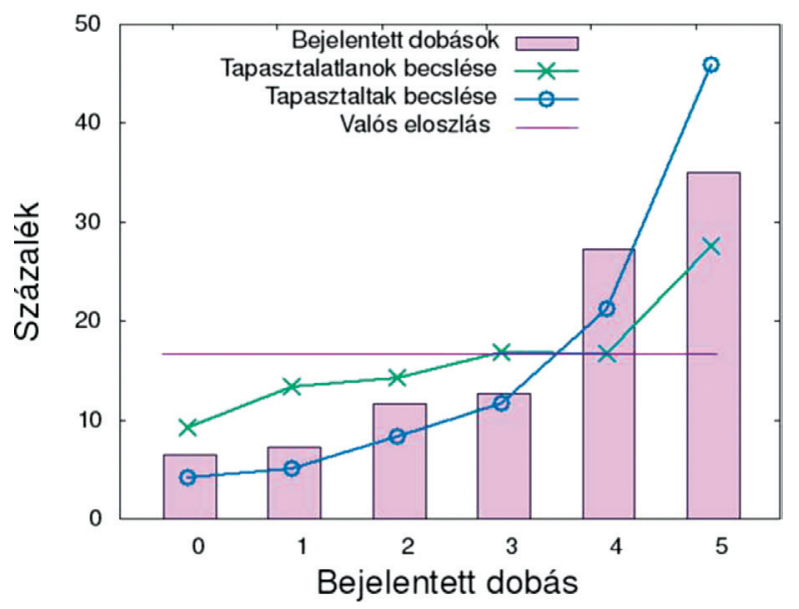

2. ábra. A résztvevők becsléséből származó eloszlások, valamint az 1. ábrán látható valódi eloszlás összehasonlítása

(Fischbacher-Föllmi-Heusi, 2013 nyomán) 
hogy a résztvevőknek lenne információjuk a többiek viselkedéséröl. A valódi eloszláshoz sokkal jobban hasonlító eloszlást tételeznek fel, sokkal több csalással, de érdekes módon úgy, hogy a maximális csalást (5-ös) felül, a rejtőzködő csalást (4-es) alul becslik (2. ábra).

E két utóbbi eredmény rámutat arra is, hogy a nem etikus viselkedéssel - esetünkben hazugsággal - szerezhető nyeremény növeli annak esélyét, hogy legközelebb is így cselekszünk, valamint annak az esélyét is, hogy másokról is ilyen viselkedést tételezünk fel.

\section{KOOPERÁCIÓ KORRUPT HELYZETBEN}

Ori Weisel és Shaul Shalvi az előző fejezetben bemutatott kísérletet alakította át úgy, hogy az társas csaló helyzetet modellezzen, azaz korrupciós dilemmákat lehessen vele vizsgálni (Weisel-Shalvi, 2015). Az egyik kísérleti beállítás mellett a játékosoknak kétszer kellett dobni a kockával, és a dobás eredményét továbbra is csak ők látják. Ha saját bevallásuk szerint kétszer ugyanazt a számot dobták, akkor annyi euró nyereséget kapnak, ahányas számot jelentenek be (írnak be a számítógépbe), ha különböző számokat jelentenek be, akkor nem kapnak jutalmat. Tehát ebben a kísérletben a legnagyobb, hateurós nyereséget két hatossal lehet elérni, aminek az esélye csupán 1/36. Ezt a kísérletet kontrollnak szánták a kísérlet egy kétszemélyes változatához. Itt két játékos játszik egyszerre. Nem látják egymást, és nem is ismerik egymást. Elöször az $A$ játékos dob egyet a kockával, és a dobott értéket (vagy bármi mást) beírja a számítógépbe. A beírt érték megjelenik a $B$ játékos előtt lévő képernyőn. Ezután $B$ is dob egyet, és beírja az általa dobott számot (vagy bármi mást) a számítógépbe. Nyerni most is akkor lehet, ha azonos számot írnak be, és a legnagyobb nyereséget a két hatos adja. Fischbacher és Föllmi-Heusi kísérletei rámutattak, hogy akik korábban részt vettek a játékban, nagyobb eséllyel fognak csalni egy újabb körben. Weisel és Shalvi kísérletében ezért minden játékos pár hússzor játszott egymással, ahogy a kontrollkísérletben is a játékos egymás után húsz alkalommal játszott. Mivel annak az esélye, hogy kétszer azonos számot dobunk 1/6, így húsz próbálkozásból ez átlagosan 20/6 $=3 \frac{1}{3}$ esetben következik be, aminek, ha mindenki becsületesen viselkedne átlagosan $(1+2+3+4+5+6) / 6 \times 3 \frac{1}{3}=11^{2} / 3$ euró nyereséget hozna, függetlenül attól, hogy egy vagy két személy játssza a játékot. Gondolom, nem meglepő, hogy a valóságban sokkal több azonos dobást jelentenek be a játékosok, mint ami várható volna, és előszeretettel ötösöket vagy hatosokat „dobnak”. Ami sokkal érdekesebb esetünkben, hogy a csalás mértéke lényegesen nagyobb, ha párban játszanak.

A páros játék esetén átlagosan több mint 16 esetben jelentenek be azonos dobást a 20 esetből, míg az egyszemélyes játék esetében ez a szám közel 11, szem- 


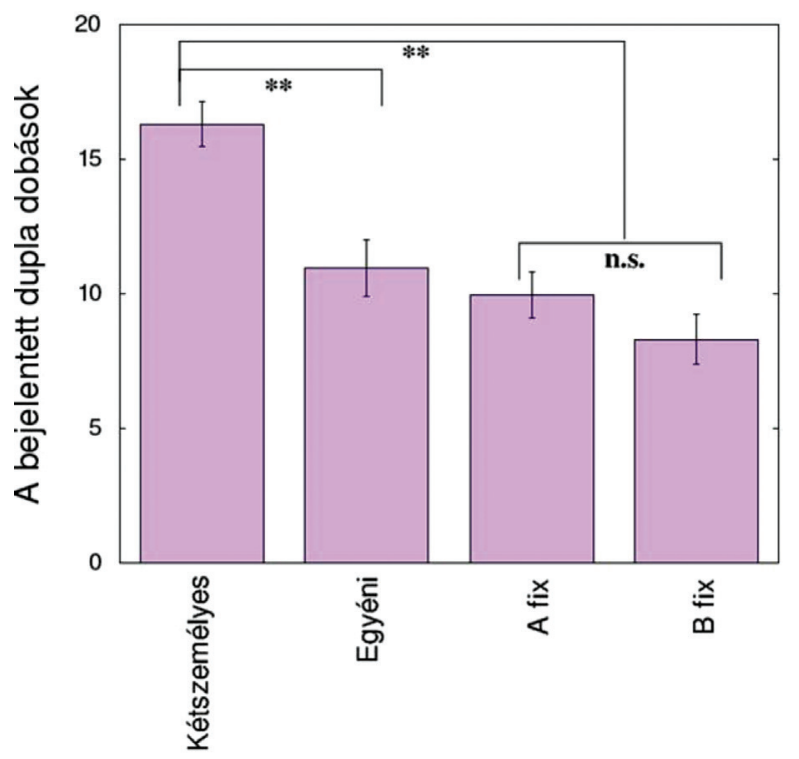

3. ábra. Az egyszemélyes és a kétszemélyes kockadobási kísérlet eredményei. A ** 5\%-os szignifikanciaszintet jelez. További magyarázat a szövegben található

(Weisel-Shalvi, 2015 nyomán)

ben a 31/3-dal, ami a valós várható érték (3. ábra). Természetesen mind a két mért érték szignifikánsan nagyobb, mint a várható érték, továbbá a páros játékban tapasztalt csalás mértéke is szignifikánsan nagyobb, mint a nem páros csalásban tapasztalté. Természetesen ezek az eltérések jelentősek, s még inkább azok, ha a nyeremény várható értékét hasonlítjuk össze a tényleges nyereménnyel, hiszen nem csupán azzal csalnak a játékosok, hogy azonos számokat jelentenek be, hanem azzal is, hogy legtöbbször ötös vagy hatos számot mondanak. Weisel és Shalvi is több további kontrollkísérletet terveztek, ahol az eredeti páros játékban módosították az $A$, illetve a $B$ játékos nyereményének szabályát. Ezek közül a leginkább érdekes az a két beállítás, amikor vagy az $A$, vagy a $B$ játékos minden kör után egy fix összeget (1 eurót) kap (A fix, illetve B fix beállítás), függetlenül attól, hogy azonos számokat jelentenek be vagy sem. A másik játékos továbbra is csak akkor kap pénzt, ha a játékosok azonos számokat jelentenek be. Persze ez továbbra is a $B$ játékoson múlik (vagy a szerencsén). Az eredmény részben sejthető, ám egyben váratlan elemeket is tartalmaz. Nyilván, ha a $B$ játékos fix összeget kap, akkor nem érdeke csaló módon azonos számot bejelentenie. Mégis elég gyakran csalni fog, ezzel nyereményhez juttatva az $A$ játékost. Ha az $A$ játékos kap fix összeget, akkor meg azt várnánk, hogy a $B$ játékos ugyanolyan intenzíven fog csalni, mint a kölcsönös érdek esetén. Ám ilyenkor is lényegesen 
alacsonyabb lesz a csalás mértéke, ráadásul az $A$ kap fix összeget és $B$ kap fix összeget esetekben a csalás mértéke nem különbözik szignifikánsan egymástól (3. ábra).

Annak ellenére, hogy elég általánosnak és jellemzőnek gondolhatjuk az imént vázolt eredményeket, más kísérletekből tudjuk, hogy a humán kooperációs viselkedésben elég nagy kulturális alapú különbségek lehetnek (lásd például Hermann et al., 2008). Ezért nem meglepő, hogy nemrég megismételték Weisel és Shalvi kísérleteit más előképzettségű hallgatókkal (Wouda et al., 2017). Talán mondanom sem kell, a bemutatott kísérletek alanyai egyetemi hallgatók voltak. Míg az imént említett kísérletsorozatban a hallgatók közgazdaságtant tanultak, a megismételt kísérletben pszichológushallgatók voltak a kísérleti alanyok. A tapasztalt mintázat hasonló volt, ám a csalás mértékét lényegesen kisebbnek mérték, mint az eredeti cikkben! Míg a közgazdászhallgatók az esetek 81,5\%-ban jelentettek be azonos számokat, addig a pszichológushallgatók csupán 29,6\%-ban. A szerzők korábbi megfigyelésekre támaszkodva fel is hívják a figyelmet arra, hogy egy közgazdasági képzésben részesülő hallgató számára a profit maximalizálása elsődleges szempont, ezért könnyebb szívvel választja a csaló, ám hasznot hozó stratégiát. A pszichológushallgatók számára a normához igazodó énkép és magas önértékelés valószínủleg fontosabb szempont, ami védettebbé teszi őket a csalással szemben. Bár az is igaz, hogy ez utóbbi kísérletben kisebb összegeket lehetett nyerni, így csalni is kevésbé volt csábító. Jeroen Wouda és munkatársai egy új kísérleti beállítást is teszteltek. A kockadobások előtt a résztvevők egyik csoportjának a Weisel-Shalvi-kísérletből származó adatokat (sok csalás), a másik csoportjának pedig a pszichológus hallgatókon végzett kísérletből származó adatokat (kevés csalás) mutatták meg. Ezután elvégezve a kockadobós kétszemélyes kísérletet, azok, akik a „sok csalás” adatsort látták, 67\%-ban jelentettek be azonos számot, akik a „kevés csalás” adatsort, azok viszont 47\%-ban.

\section{KOMMUNIKÁCIÓ, MORÁLIS ERÓZIÓ, KORRUPCIÓ}

Egy másik nagyon frissen megjelent publikációban a kockadobós ötletre alapozva egy olyan kísérletsorozatot terveztek, ahol az egyik beállításban a tagok a döntés előtt egy csetelő felületen keresztül beszélhettek egymással a csoportban. A cél tehát elsősorban az volt, hogy feltérképezzék, hogy a tagok közötti kommunikáció hogyan hat a csalás gyakoriságára (Kocher et al., 2017). Három kísérleti beállítást alkalmaztak (4. ábra). Az első esetben a három egymást követő kísérletben a játékosok a Fischbacher és Föllmi-Heusi által bevezetett egyéni játékot játszszák (egyéni). A második és harmadik beállításnál az első és a harmadik körben egyéni játék van, de a második körben a játékosok véletlenszerü sorsolással egy hármas csoportba kerülnek. A képernyőn mind a hármuknál megjelenik, hogy 


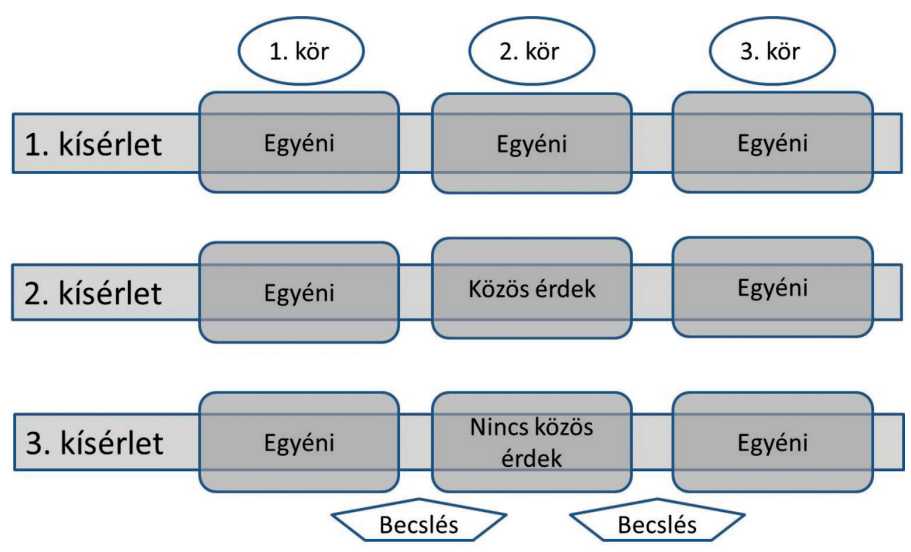

4. ábra. A kísérleti beállítások a többiek viselkedését becslő fázisokkal. Az egyes kísérletek részletesebb leírása a szövegben olvasható

(Kocher et al., 2017 nyomán)

a gép hányas számot dobott nekik, illetve a társaiknak. Ezután lesz lehetőségük beírni a számítógépbe, hogy hányas számot „kaptak” a géptől. Akkor nyernek, ha mind a hárman ugyanazt a számot írják ki a képernyőre, és a nyereményük annyi lesz euróban, ahányas számot jelentettek be (közös érdek). (Ha három hatost vagy különböző számokat jelentenek be, akkor nincs nyereség, tehát a maximális nyereség 5 euró volt személyenként.) A döntés elött azonban a játékosoknak lehetőségük volt 5 percig egy csetes felületen beszélgetni. Természetesen azt nem tudják, hogy ki kivel játszik, és kivel beszélget, így a fenyegetés és vesztegetés is kizárt. A harmadik beállítás nagyon hasonló volt az előzőhöz, azonban itt a második, csoportos játékkörben minden játékos annyi eurót kapott, amekkora számot beírt, függetlenül attól, mit írtak a többiek (nincs közös érdek), ám a döntés elött itt is volt 5 percük csetelni a többiekkel.

Továbbá, hasonlóan Fischbacher és Föllmi-Heusi kísérletéhez minden kísérletsorozat előtt a játékosok becslést tettek a bejelentett dobások eloszlására, amit az elért pontosság függvényében jutalmaztak is.

A korábbi eredmények és személyes tapasztalataink alapján nem lepődünk meg azon, hogy csoportos, kommunikációs helyzetben ilyenkor is szignifikánsan gyakrabban csalnak a játékosok. Érdekes azonban, hogy a csalási arányban nincs szignifikáns különbség a közös érdek és a nincs közös érdek esetek között. Ahogy a korábbi kísérleteknél már tapasztaltuk, itt is megfigyelhető volt, hogy minél több kört játszott valaki, annál inkább gondolta, hogy a többiek (is) csalni fognak, és természetesen ez így is történt. A csoportos kommunikációs helyzet fokozta ezt a negatív várakozást. Ennek hátterét is sikerült elemezni, ugyanis a cseten elhangzó beszélgetések elemzésével kimutatták, hogy a beszélgetések 
során lényegesen gyakrabban jelenik meg a nem öszinte viselkedésre, mint az őszinte viselkedésre buzdítás. A csalásra buzdítás általában a pénzzel mint érveléssel együtt jelenik meg. A beszélgetések elemzéséből az is kiderült, hogy az őszinteségre sarkalló érvek növelték az öszinteséget, míg a csalásra buzdítók csökkentették azt. Egy további nagyon meggyőző kontrollkísérletről is beszámolnak a szerzők. Az egyéni játékbeállítást úgy változtatták meg, hogy a döntés előtt mindenki kapott 5 percet, hogy leírja a gondolatait. Beszélgetni nem volt mód. A csalás lehetősége legalább annyiszor megjelent ezekben a gondolatokban, a csalás gyakorisága viszont nem növekedett az egyéni beállításhoz képest. Talán érdekes még megemlíteni, hogy a csalásra való hajlamot a résztvevők sokféle jellemzőjével próbálták korrelációba hozni (machiavelliánus személyiségjegy, a big five személyiségvonások, nem, politikai attitüd, életkor, vallásosság). Azonban csak a nemek között találtak különbséget: az egyéni esetben a nők őszintébbek, de a kommunikációs helyzet hatására kevésbé lesznek azok, mint a férfiak.

\section{ÖSSZEGZÉS}

Az eredmények alapján kézenfekvő a megállapítás, hogy igen könnyen eldobjuk a mondj igazat normát, ha ezzel anyagi előnyre tehetünk szert. Bár nem tértem ki erre korábban, a kontrollkísérletek alapján ez akkor is így van, ha ezt nem lehetett eltitkolni a kísérletvezető elött (Fischbacher-Föllmi-Heusi, 2013; Kohler et al., 2017). A hazugság, kulturális háttértől függetlenül elítélendő, a hazug hírneve és így a szaporodási és/vagy túlélési sikere is csökken a csoportban. Ám a kísérletvezető nem tagja a kísérleti személyek referenciacsoportjának, így nem is érzik hátrányosnak a jelenlétében hazudni. Weisel és Shalvi kísérletei elsősorban arra mutatnak rá, hogy a közös érdek és a közös csalás jelentösen növeli a nem öszinte, korrupt viselkedést. Cikkükben föképp azt hangsúlyozzák, hogy paradox módon az emberben meglévő kooperációs késztetés az, ami e korrupt helyzetben jelentősen növeli a csaló viselkedést. Véleményem szerint fontos azt is észrevenni, hogy ebben a kísérletsorozatban többször is játszik egymással ugyanaz a két játékos, ezért minden korábbi körben a valószínüleg csaló viselkedés (például $A$ játékos hatost jelent be egymás után többször, vagy $B$ játékos következetesen ugyanazt jelenti be, amit $A$ mondott) egyben a csaló viselkedés elfogadására buzdítás. Tehát kommunikáció is zajlik a játékosok között. Martin G. Kocher és munkatársainak eredményei éppen arra világítanak rá, hogy a csoporton belüli kommunikáció gyors értékrendváltást, vagy mondjuk ki: morális leépülést okoz, és ez akkor is így van, ha nincs közös érdek a tagok között. Nagyon könnyű belecsúszni a korrupt döntésbe, ha látjuk, hogy a többiek is helyesnek tartják ezt, hiszen így értékelésünk és önértékelésünk nem csökken a többiekhez képest. Wouda és munkatársai rövidke cikkükben pedig azt igazolják, hogy a kísérleti személyek 
értékrendje, illetve a viselkedési minta jelentősen befolyásolja a csaló viselkedés gyakoriságát. Lefordítva a hétköznapi életre: egy ország mintaadó rétegeiben tapasztalható korrupció káros hatása lényegesen nagyobb, mint a közvetlenül okozott kár, bár esetenként ez sem elhanyagolható (Burai, 2017).

A csoportos élet, a kooperáció és az intenzív kommunikáció voltak az ember evolúciójának legfontosabb alappillérei. Amikor a hétköznapi életben a kommunikációról és a kooperációról van szó, akkor annak a csoport hatékony müködésére gyakorolt pozitív hatásaira gondolunk, hiszen ezekre alapvetően szükség van a koordinált munkavégzéshez, a szociális kohézióhoz. Azonban a bemutatott kísérletek rámutatnak, hogy ezek a jellemvonásaink a modern társadalmakban táptalajul szolgálnak a korrupt csoport megjelenéséhez is. Ezért szükség van a társadalomban megjelenő csoportosulások folyamatos külső kontrolljára (fékek és ellensúlyok), és ha szükséges, az aktív beavatkozás sem kerülhető el. A csoporttudat és a csoportelőny keresése annyira erős az emberben, hogy a korrupt együttmüködés csökkentése érdekében a csoportnormákat és a fókuszt folyamatosan karban kell tartani.

A bemutatott kísérleti megközelítés viszonylag új, ezért segítségével várhatóan számos további hatást is vizsgálni fognak a jövőben. Azonnal felmerül a kérdés, hogy vajon mi lehet a szerepe a csoporton belüli hierarchiának vagy a büntetésnek a csaló viselkedés visszaszorításában? Esetleg a lebukás esélyének növelésével lehet-e jobban csökkenteni a korrupt nyerészkedők arányát?

A cikk végén térjünk vissza Móricz Zsigmond Rokonok címü regényéhez. Kötelező olvasmány, közös kultúrkincsünk, merítsünk hát bölcsességéből! A regény rendkívül érzékletesen mutatja be, ahogy Kopjáss Pista szemlélete és viselkedése átalakul, ahogy kezdi átvenni új csoportja, a zsarátnoki hatalmasságok korrupt értékrendjét. Kopjáss, a zürös hátterü Boronkay-villa mélyen áron aluli megvásárlása után maga is kimondja: „Az igazat megvallva, nincs rá szükségem. Eddig is megéltem a magam tiszta, egyszerü életében, ezt ezután is meg lehet tenni.

De hiába mondta ki ilyen hevesen és önérzetesen ezt magában, már érezte, hogy nincs így.

Valamit változott a helyzet."

Mert a „helyzet” könnyen változik. De jó lenne, ha végre a jó irányba változna!

\section{KÖSZÖNETNYILVÁNITÁS}

A cikk a GINOP-2.3.2-15-2016-00057 pályázatának támogatásával készült. 


\section{IRODALOM}

Burai P. (2017): „Muszáj jobbnak lenni” Kiutak a korrupcióból. In: Jakab A. - Urbán L (szerk.): Hegymenet. Társadalmi és politikai kihívások Magyarországon. Budapest: Osiris Kiadó, 309-325.

Fischbacher, U. - Föllmi-Heusi, F. (2013): Lies in Disguise-An Experimental Study on Cheating. Journal of the European Economic Association, 11, 3, 525-547. DOI: 10.1111/jeea.12014

Hermann, B. - Thöni, C. - Gachter, S. (2008): Antisocial Punishment across Societies. Science, 319, 1362-1369. DOI: 10.1126/science.1153808

Kocher, M. G. - Schudy, S. - Spantig, L. (2017): I Lie? We Lie! Why? Experimental Evidence on a Dishonesty Shift in Groups. Management Science (megjelenés előtt), https://doi.org/10.1287/ mnsc. 2017.2800

Weisel, O. - Shalvi, S. (2015): The Collaborative Roots of Corruption. Proceedings of the National Academy of Sciences of the USA. 112, 34, 10651-10656. DOI: 10.1073/pnas.1423035112, http:// www.pnas.org/content/112/34/10651

Wouda, J. - Bijlstra, G. - Frankenhuis, W. E. - Wigboldus, D. H. J. (2017): The Collaborative Roots of Corruption? A Replication of Weisel \& Shalvi (2015): Collabra: Psychology, 3, 1, 27, 1-3. DOI: 10.1525/collabra.97, https://www.collabra.org/articles/10.1525/collabra.97/

URL1: https://www.transparency.org/what-is-corruption 